\title{
Drug-induced Liver Injury Caused by Phenprobamate: Strong Probability Due to Repeated Toxicity
}

\author{
Tolga Duzenli ${ }^{1}$, Alpaslan Tanoglu ${ }^{2}$, Taner Akyol ${ }^{3}$, Muammer Kara ${ }^{4}$, Yusuf Yazgan ${ }^{5}$
}

\begin{abstract}
Drug-induced liver injury (DILI) is an important cause of morbidity and mortality. DILI can even cause acute liver failure and the need for liver transplantation. Identifying DILI may be particularly difficult because it is actually an exclusion diagnosis and individuals are usually exposed to several drugs during a lifetime. Causality assessment methods are needed for objective diagnosis. The most common methods are; updated Roussel Uclaf causality assessment method (RUCAM), Narenjo adverse drug reaction probability scale and Maria and Victorino (M\&V) causality assessment scale. Phenprobamate is a widely used muscle relaxant. Herein we report a rare case of repeated DILI caused by phenprobamate and review the objective diagnostic process for hepatotoxicities. Physicians should be aware of the potential adverse effects of this drug, including hepatotoxicity.
\end{abstract}

Keywords: Drug-induced liver injury, Phenprobamate, Toxicity.

Euroasian Journal of Hepato-Gastroenterology (2019): 10.5005/jp-journals-10018-1295

\section{INTRODUCTION}

$\mathrm{D}$ rug-induced liver injury (DILI) is an important cause of morbidity and mortality. DILI can even cause acute liver failure and need for liver transplantation. Identifying DILI may be particularly difficult because it is actually an exclusion diagnosis and individuals are usually exposed to several drugs during lifetime. ${ }^{1-3}$ Causality assessment methods are needed for objective diagnosis. The most common methods are; updated Roussel Uclaf causality assessment method (RUCAM), Narenjo adverse drug reaction probability scale and Maria and Victorino (M\&V) causality assessment scale. ${ }^{2,3}$ Phenprobamate is a widely used muscle relaxant in sports medicine. ${ }^{4}$ Herein, we report a rare case of repeated DILI caused by phenprobamate. Informed consent is obtained from the patient for the publication of his information and imaging.

\section{Case report}

A 28-year-old male patient admitted to our department with complaints of jaundice at the skin, eye, and urine. He had no comorbidities, preexisting liver disease, ethanol or smoking history. He had phenprobamate use for muscle relaxation for 2 weeks and had no other treatment, herbal use or drug addiction. At physical examination, scleras and skin were quite icteric. He had no other pathological findings as rash, fever, arthritis, etc. Neurologic or psychiatric examinations were normal. Laboratory results at admittance are presented in the table by day one (Table 1). The patient had a history of hospitalization one year ago with a similar condition of DILI. At that time, evaluation was made and after the exclusion of all other diseases; the patient was followed-up with the "probable" diagnosis of phenprobamate toxicity. After the withdrawal of phenprobamate, everything about liver got better and fully recovered. But unfortunately, he had begun the same drug again by himself 2 weeks ago for muscle spasms.

We stopped the offending medication and ruled out other potential causes of liver injury by laboratory and radiological screening tests. Viral causes as hepatitis A, B, C, D, E viruses, cytomegalovirus (CMV), ebstein barr virus (EBV), herpes simplex virus (HSV), varicella zoster virus (VZV); biliary obstruction (by ultrasonography); autoimmune etiology by antinuclear antibody (ANA), antismooth-
1,2,4,5 Department of Gastroenterology, Sultan Abdulhamid Han Training and Research Hospital, Istanbul, Turkey

${ }^{3}$ Department of Gastroenterology, Samsun Gazi State Hospital, Samsun, Turkey

Corresponding Author: Tolga Duzenli, Department of Gastroenterology, Sultan Abdulhamid Han Training and Research Hospital, Istanbul, Turkey, Phone: +90216422020/3502, e-mail: tolgaduzenli@ yahoo.com

How to cite this article: Duzenli T, Tanoglu A, et al. Drug-induced Liver Injury Caused by Phenprobamate: Strong Probability Due to Repeated Toxicity. Euroasian J Hepatogastroenterol 2019;9(1):49-51.

Source of support: Nil

Conflict of interest: None

muscle antibody (ASMA), anti-liver kidney microsomal antibody (anti-LKM), antimitochondrial antibody (AMA), immunoglobulin G/ G4; genetic diseases as Wilson, Hemochromatosis, a-1 antitrypsin deficiency excluded. Thereafter; we monitored the patient to ensure liver tests normalize. Within one month of withdrawal, laboratory results were significantly normalized.

\section{Discussion}

DILI can develop following the use of many drugs. A high index of suspicion is often necessary to expeditiously establish the diagnosis. It depends on obtaining a careful drug use history and ruling out other potential causes of liver injury. ${ }^{2,3}$ There are no specific serum biomarkers or characteristic histologic features that reliably identify a drug as the cause of hepatic injury. ${ }^{1-3}$ Causality assessment methods should be used for the correct diagnosis. ${ }^{2,3}$ As the most common methods, our patients' score of updated RUCAM were 9 (Table 2), Narenjo adverse drug reaction probability scale was 8 and M\&V causality assessment scale were 12 , suggesting a likely causal relationship between phenprobamate and toxicity. ${ }^{4-6}$

In the literature, phenprobamate toxicity has revealed itself with neurologic and psychiatric symptoms and treated by hemoperfusion and plasmapheresis. ${ }^{7,8}$ In Emet et al. study, their case of phenprobamate overdose (20 tablets of phenprobamate

(o) The Author(s). 2019 Open Access This article is distributed under the terms of the Creative Commons Attribution 4.0 International License (https://creativecommons. org/licenses/by-nc/4.0/), which permits unrestricted use, distribution, and non-commercial reproduction in any medium, provided you give appropriate credit to the original author(s) and the source, provide a link to the Creative Commons license, and indicate if changes were made. The Creative Commons Public Domain Dedication waiver (http://creativecommons.org/publicdomain/zero/1.0/) applies to the data made available in this article, unless otherwise stated. 
Drug-induced Liver Injury Caused by Phenprobamate: Strong Probability Due to Repeated Toxicity

Table 1: Lab monitorization of the patient (days indicate hospitalization and withdrawal periods)

\begin{tabular}{|c|c|c|c|c|c|c|c|c|}
\hline & $A L T(U / L)$ & $A S T(U / L)$ & $A L P(U / L)$ & GGT (U/L) & D.Bil $(\mathrm{mg} / \mathrm{dL})$ & T.Bil (mg/dL) & Albumin ( $g / d L)$ & INR \\
\hline $\begin{array}{l}\text { 1-year ago-first hospitalization } \\
\text { with "probable" DILI }\end{array}$ & 1256 & 989 & 156 & 256 & 5.36 & 7.02 & - & - \\
\hline 6 months ago-control & 30 & 25 & 72 & 49 & 0.28 & 0.97 & 3.92 & 1.10 \\
\hline Day 1 & 4133 & 1630 & 146 & 399 & 9.06 & 11.86 & 4.68 & 1.12 \\
\hline Day 7 & 1524 & 1233 & 104 & 116 & 7.72 & 11.39 & 3.74 & 1.18 \\
\hline Day 14 & 947 & 395 & 85 & 91 & 1.83 & 2.93 & 3.89 & 1.07 \\
\hline Day 21 & 432 & 128 & 84 & 81 & 1.06 & 1.82 & 3.96 & 1.09 \\
\hline Day 28 & 122 & 56 & 76 & 56 & 0.34 & 1.20 & 4.12 & 1.08 \\
\hline Day 180 (outpatient) & 28 & 20 & 68 & 51 & 0.25 & 0.93 & - & -- \\
\hline
\end{tabular}

DILI, drug induced liver injury; ALT, alanine aminotransferase; AST, aspartat aminotransferase; ALP, alkaline phosphatase; GGT, gamma glutamyl transferase; D.Bil, direct bilirubine; T.Bil, total bilirubine; INR, international normalized ratio; U/L, units per litre; mg/dL, milligrams per decilitre; $\mathrm{g} / \mathrm{dL}$, grams per decilitre

Table 2: The patients' updated RUCAM for the cholestatic or mixed liver injury of DILI ${ }^{4}$

\begin{tabular}{|c|c|c|}
\hline Items for cholestatic or mixed liver injury & Score & Result \\
\hline \multicolumn{3}{|l|}{ 1. Time to onset from the beginning of the drug/herb } \\
\hline 5-90 days (rechallenge: $1-90$ days) & +2 & +2 \\
\hline$<5$ or $>90$ days (rechallenge: $>90$ days) & +1 & \\
\hline $\begin{array}{l}\text { Alternative: Time to onset from cessation of the drug/herb } \\
\text { (except for slowly metabolized chemicals: } \leq 30 \text { days) }\end{array}$ & +1 & \\
\hline \multicolumn{3}{|l|}{ 2. Course of ALP after cessation of the drug/herb } \\
\hline Decrease $\geq 50 \%$ within 180 days & +2 & +2 \\
\hline Decrease $<50 \%$ within 180 days & +1 & \\
\hline No information, persistence, increase, or continued drug/herb use & 0 & \\
\hline 3. Risk factors & & 0 \\
\hline Alcohol use current drinks/d: >2 for women, $>3$ for men) & +1 & \\
\hline Alcohol use (current drinks/d: $\leq 2$ for women, $\leq 3$ for men) & 0 & \\
\hline Pregnancy & +1 & \\
\hline Age $\geq 55$ years & +1 & \\
\hline Age $<55$ years & 0 & \\
\hline 4. Concomitant use of drug(s)/herb(s) & & 0 \\
\hline None or no information & 0 & \\
\hline Concomitant drug/herb with incompatible time to onset & 0 & \\
\hline Concomitant drug/herb with compatible or suggestive time to onset & -1 & \\
\hline Concomitant drug/herb known as hepatotoxin and with compatible or suggestive time to onset & -2 & \\
\hline Concomitant drug/herb with evidence for its role in this case (positive rechallenge or validated test) & -3 & \\
\hline 5. Search for alternative causes & Tick if & Tick if not \\
\hline Group I (7 causes) & neg. & done \\
\hline HAV: Anti-HAV-lgM & - & \\
\hline HBV: HBsAg, anti-HBc-IgM, HBV-DNA & - & \\
\hline HCV: Anti-HCV, HCV-RNA & - & \\
\hline HEV: Anti-HEV-IgM, anti-HEV-IgG, HEV-RNA & - & \\
\hline Hepatobiliary sonography/colour Doppler sonography of liver vessels/endosonography/CT/MR & - & \\
\hline Alcoholism (AST/ ALT $\geq 2$ ) & & \\
\hline Acute recent hypotension history (particularly if underlying heart disease) & - & \\
\hline Group II (5 causes) & - & \\
\hline $\begin{array}{l}\text { Complications of underlying disease(s) such as sepsis, metastatic malignancy, autoimmune hepatitis, } \\
\text { chronic hepatitis B or C, primary biliary cholangitis or sclerosing cholangitis, genetic liver diseases }\end{array}$ & & \\
\hline Infection suggested by PCR and titer change for & - & \\
\hline CMV (anti-CMV-IgM, anti-CMV-IgG) & & \\
\hline EBV (anti-EBV-lgM, anti-EBV-IgG) & & \\
\hline HSV (anti-HSV-IgM, anti-HSV-lgG) & & \\
\hline VZV (anti-VZV-IgM, anti-VZV-IgG) & - & \\
\hline Evaluation of group I and II & - & \\
\hline All causes_-groups I and II-reasonably ruled out & - & \\
\hline The 7 causes of group I ruled out & - & \\
\hline
\end{tabular}


Cont...

\begin{tabular}{|c|c|c|}
\hline Items for cholestatic or mixed liver injury & Score & Result \\
\hline $\begin{array}{l}6 \text { or } 5 \text { causes of group I ruled out } \\
\text { Less than } 5 \text { causes of group I ruled out } \\
\text { Alternative cause highly probable }\end{array}$ & $\begin{array}{l}+2 \\
+1 \\
0 \\
-2 \\
-3\end{array}$ & +2 \\
\hline $\begin{array}{l}\text { 6. Previous hepatotoxicity of the drug/herb } \\
\text { Reaction labeled in the product characteristics } \\
\text { Reaction published but unlabelled } \\
\text { Reaction unknown }\end{array}$ & $\begin{array}{l}+2 \\
+1 \\
0\end{array}$ & 0 \\
\hline $\begin{array}{l}\text { 7. Response to unintentional reexposure } \\
\text { Doubling of ALP with the drug/herb alone, provided ALP below } 2 \mathrm{~N} \text { before reexposure } \\
\text { Doubling of ALP with the drugs(s)/herbs(s) already given at the time of the first reaction } \\
\text { The increase of ALP but less than N in the same conditions as for the first administration } \\
\text { Other situations }\end{array}$ & $\begin{array}{l}+3 \\
+1 \\
-2 \\
0\end{array}$ & +3 \\
\hline
\end{tabular}

Total score for the case 9

ALT, alanine aminotransferase; AST, aspartate aminotransferase; $A L P$, alkaline phosphatase; $H A V$, hepatitis $A$ virus; $H B V$, hepatitis $B$ virus; $H C V$, hepatitis C virus; HDV, hepatitis D virus; HEV, hepatitis E virus; CMV, cytomegalovirus; EBV, Ebstein Barr virus; HSV, Herpes simplex virus; VZV, Varicella Zoster virus; CT, computerised tomography; MR, magnetic resonance imaging; IgM, Immunoglobulin M; IgG, Immunoglobulin G; PCR, polymerase chain reaction; DNA, deoxyribonucleic acid; RNA, ribonucleic acid; N: normal

$400 \mathrm{mg}$, total dose: $8 \mathrm{~g}$ ) was presented with various muscular and neurological symptoms. ${ }^{7}$ The patient had received gastric lavage, activated charcoal, and hemodialysis. After a poor symptomatic recovery, she also had undergone plasmapheresis which revealed complete resolution of symptoms. During her follow-up, she also had transient hyperbilirubinemia and alkaline phosphatase elevation. Tasdemir et al. case was a 16 years old male adolescent presented with drowsiness and confusion which had 37 tablets (14.8 g) of phenprobamate with other drugs. ${ }^{8}$ The highest dose was of phenprobamate. By early haemoperfusion and supportive care; the patient had recovered completely.

Our patient had a cumulative toxic dose of phenprobamate rather than acute ingestion and was presented with mixed (cholestatic and liver) type DILI. ${ }^{9}$ Serum levels of phenprobamate could not be determined but fortunately, our patient had also recovered by supportive care. In the literature, there is no requirement of transplantation or any methods for prevention for these patients. Also, there is one case report with abuse and dependence of phenprobamate. ${ }^{10}$ But our patient is not compatible with this context. In addition to that; Balcı Sengul et al. indicated that phenprobamate was one of the most abused drugs in prisons in Turkey. ${ }^{11}$

In conclusion, although it is generally known that phenprobamate is a safe and effective therapeutic agent for muscle relaxation, physicians should be aware of potential adverse effects of this drug, including hepatotoxicity. Dose reductions or mainly discontinuation of the drug may be needed in such clinical circumstances.

\section{References}

1. Tujios SR, Lee WM. Acute liver failure induced by idiosyncratic reaction to drugs: Challenges in diagnosis and therapy. Liver Int 2017 Aug 3.

2. Raschi E, De Ponti F. Drug-induced liver injury: Towards early prediction and risk stratification. World J Hepatol 2017;9(1):30-37.

3. Andrade RJ, Ortega-Alonso A, et al. Drug-Induced Liver Injury Clinical Consortia: a global research response for aworldwide health challenge.Expert Opin Drug Metab Toxicol 2016;12(6):589-593.

4. Danan G, Teschke R. RUCAM in drug and herb induced liver injury: The Update. Int J Mol Sci 2015;17(1). pii: E14.

5. Naranjo CA, Busto U, et al. A method for estimating the probability of adverse drug reactions. Clin Pharmacol Ther 1981;30(2): 239-245.

6. Maria VA, Victorino RM. Development and validation of a clinical scale for the diagnosis of drug-induced hepatitis. Hepatology. 1997 Sep;26(3):664-669.

7. Emet $\mathrm{M}$, Aslan $\mathrm{S}$, et al. Plasmapheresis is useful in phenprobamate overdose. Am J Emerg Med 2009;27(5):626.e1-e2.

8. Tasdemir HA, Yildiran A, et al. Haemoperfusion may be useful in phenprobamate and polypharmacy intoxication of paediatric patients. Nephrol Dial Transplant.2002;17(5):941.

9. Tulunay FC, Onaran $\mathrm{HO}$, et al. Pharmacokinetics of phenprobamate after oral administration to healthy subjects. Arzneimittelforschung 1998; 48:1068-1071.

10. Demir B, Demir Y, et al. Phenprobamate dependence: a case report. Addict Behav. 2015;45:232-233.

11. Sengul BC, Sengul $C$, et al. Is Prescription Drug Abuse in Prisons Changing? A Preliminary Study with Prison Doctors. J Depend 2015;16(3):113-118. 